\title{
“Indikator på samfunnets patologi”. Om DDR og suicidraters politiske betydning
}

\author{
Ved Arne Thorvik
}

\section{ABSTRACT}

"Indikator på samfunnets patologi”. Om DDR og suicidraters politiske betydning Artikkelen tar for seg suicidratene i det tidligere DDR (Tyske demokratiske republikk) i perioden staten eksisterte (194990), og drøfter mulige forklaringsmodeller på at ratene lå på europeisk toppnivå. Der nest tematiseres hvordan suicid ble forstått, ideologisk og forskningsmessig, i en statsdannelse basert på marxistisk tenkning. En kjent kasuistikk (pastor Oskar Brüsewitz) presenteres. Et overordnet siktemål for artikkelen er å anskueliggjøre at suicidrater ikke bare er en stringent medisinsk variabel, men lett tillegges en politisk betydning som "indikator på samfunnets patologi". De høye ratene i DDR var åpenbart kontrære til regimets $\varnothing$ nske om at DDR skulle fremstå som en mønsterstat. Den $\varnothing$ kende hemmeligholdelsen av suicidrater på 1960- og 70tallet illustrerer dette. Artikkelen nevner også eksempler fra Skandinavia på at suicidrater er blitt tillagt en politisk betydning. Avslutningsvis diskuteres hvorvidt det kan være berettiget å se suicidrater som en indikator på et funksjonelt eller dysfunksjonelt politisk system.

GDR and the political significance of suicide rates

This article deals with suicide rates in the former GDR (German Democratic Republic) during the decades this state was existent (1949-90), and presents possible explanations to the fact that these rates were among the highest in Europe. Next, the article discusses how the phenomenon of suicide was evaluated, ideologically and according to research, within a state based on Marxist philosophy. A well-known case (the Rev. Oskar Brüsewitz) is mentioned. Extensively, the article aims to illustrate that suicide rates are not only a restricted medical variable. A political significance ("indicator of social pathology") is easily attributed. It seems obvious that high suicide rates were contrary to the official project of presenting GDR as a model state. This is further supported by the fact that suicide rates were increasingly classified by the regime during the nineteen-sixties and seventies. In addition, the article exemplifies that a political significance has been attributed even to Scandinavian suicide rates. In the concluding remarks, the author discusses whether it might be justified to consider suicide rates an indicator of the function (or dysfunction) of a political system.

LEVERT: $\quad$ 19.07.11 REVIDERT: $\quad 23.09 .11$ AKSEPTERT: 30.09 .11
Artikkelen tar for seg suicidratene i det tidligere DDR i perioden staten eksisterte (1949-90), og drøfter mulige forklaringsmodeller på at ratene lå på europeisk toppnivå. Dette var åpenbart kontrært til regimets ønske om at DDR skulle fremstå som en mønsterstat. Et siktemål for artikkelen er derfor å vise at suicidrater ikke bare er en stringent medisinsk variabel, men lett tillegges en politisk betydning.

\section{Innledning}

Filmen De andres liv (Das Leben der Anderen) ble vist på norske kinoer for få år tilbake, og tar for seg forholdene i Den tyske demokratiske republikk (DDR) på midten av 1980-tallet.

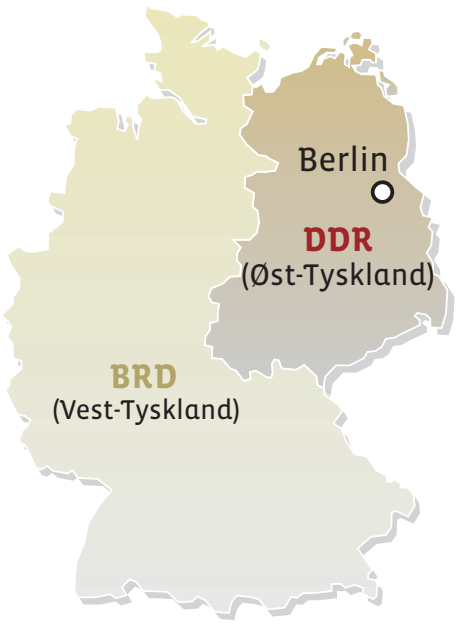

En scene viser begravelsen til en regiss $ø$ r, Albert Jerska. Det kommer frem at myndighetene hadde ilagt Jerska yrkesforbud på grunn av hans politiske meninger, og at han i tiden før han suiciderte opplevde фkende isolasjon og håpløshet.

Idet kisten senkes, bemerker en opposisjonell forfatter lavmælt: "Statistikkontoret i Hans Beimlers Straße teller alt, vet alt. (...) Men det er en ting de ikke teller, kanskje fordi byråkratene også synes at det er vondt, og det er selvmord ("Freitod"). "Hvis du ringer Beimler Straße for å spørre hvor mange mellom Elben og Oder, mellom Østersjøen og Erzgebirge som drives i døden av desperasjon, er tallorakelet vårt taust. Men de noterer kanskje navnet ditt for sikkerhetstjenesten. (...) Siden 1977 sluttet landet vårt å telle selvmord. (...). Da vi sluttet å telle, var det bare ett land i Europa som hadde flere selvmord pr. innbygger: Ungarn. Vi kom som nummer to, landet med 'virkelig eksisterende sosialisme'" (Donnersmarck 2006).

Senere i filmen er vi vitne til hvordan en gruppe opposisjonelle fors $\varnothing$ ker å smugle en artikkel om DDRs reelle suicidproblematikk over til Vest-Tyskland.

\section{Målsetning og metode}

Denne artikkelen har som målsetning å gi en kortfattet presentasjon av suicidraters historikk i Den tyske demokratiske republikk (DDR), et land som ved oppløsningen i 1990 hadde anslagsvis 16 millioner innbyggere. Videre fors $\varnothing$ kes belyst hvordan suicid ble forstått, ideologisk og forskningsmessig, innen en stat som var basert på marxistisk tenkning. Med dette som utgangspunkt er det et siktemål å utdype problemstillingen som blir antydet i innledningen: At høye suicidrater kan tillegges en politisk betydning (og da utover umiddelbar helsepolitikk). For å illustrere dette gis også eksempler fra Skandinavia.

Artikkelen er i første rekke basert på den tyske historikeren Udo Grashoffs verk fra 2006 om suicid i DDR, videre to fagb $\varnothing$ ker utgitt i DDR mens staten ennå eksisterte (Grashoff 2006; Schwarz et al 1971; Schulze 1986). Tilhørende referanser, og litteratur som er kjent for artikkelforfatteren, er også lagt til grunn. I tillegg er det den 16. februar 2011 gjort to søk i PsychInfo, først med søkeordene "suicide" og "Eastern Europe", dernest "suicide" og "political processes". Artikkeltitler og sammendrag ble studert, og fulltekst hentet inn dersom disse tydet på at artikkelen hadde relevans.

Uttrykket "samfunnets patologi" er inspirert av en av de nevnte fagb $\varnothing$ kene fra DDR. Like fullt er det forfatterens grunnsyn at en rendyrket medisinsk forståelse av fenomenet suicid er utilstrekkelig. 


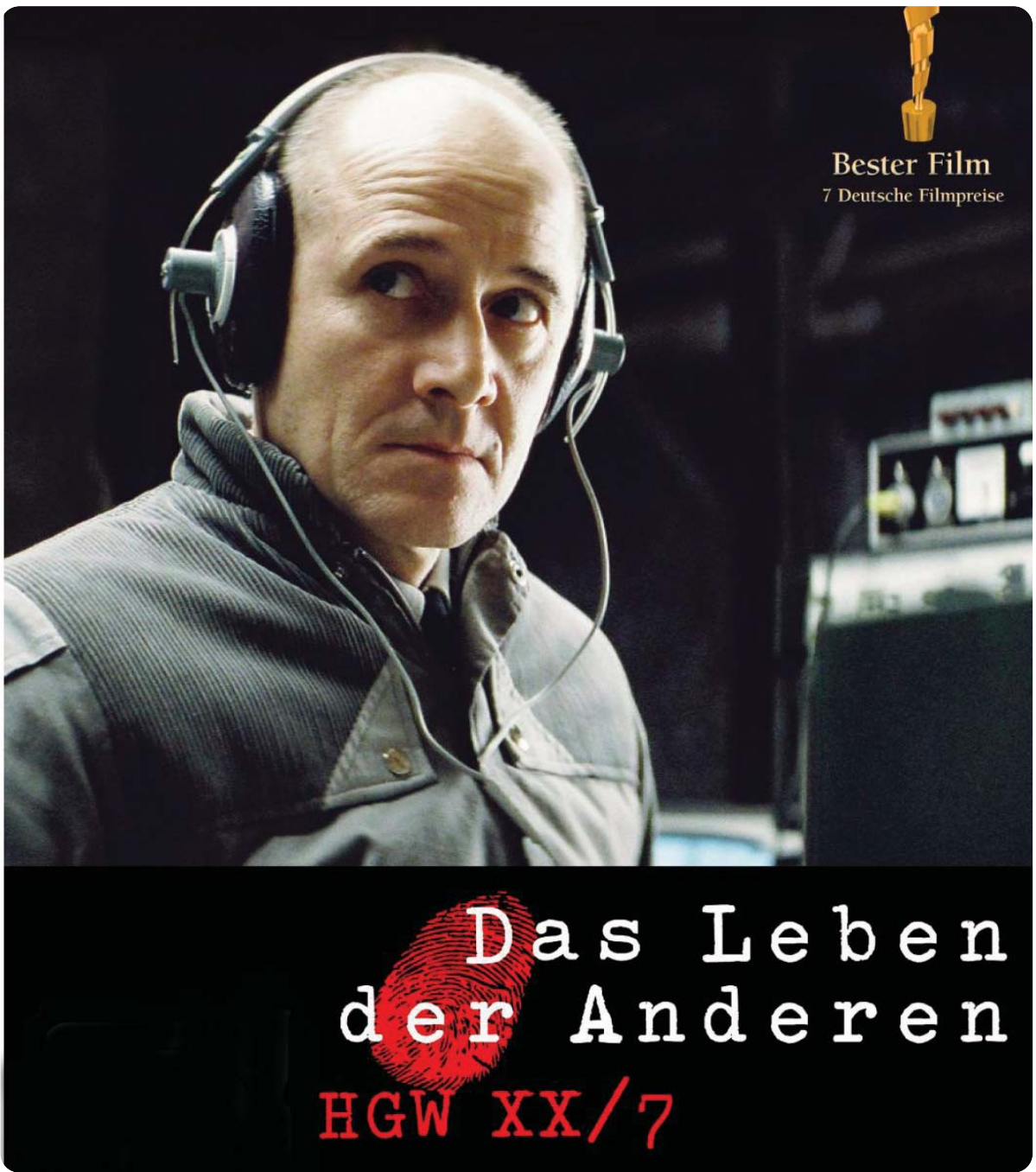

Det gjennomkontrollerte samfunn. De andres liv (Donnersmarck 2006).

Også sosiale og menneskeskapte forhold er relevante for suicidologi, ved at de kan påføre enkeltmennesket eller hele grupper en uforholdsmessig lidelse eller ubehag (Hammerlin 2010; Vetlesen 2009).

\section{Kort historikk}

DDR ( $\varnothing$ st-Tyskland) ble bokstavelig talt grunnlagt på Hitler-Tysklands ruiner. Etter fire år med sovjetisk okkupasjon ble staten, som omfattet de фstlige delene av Tyskland, opprettet i oktober 1949. En oppstand i 1953 kom til å bli brutalt slått ned av politi og sovjetisk st $\varnothing$ ttede styrker. Økende flukt til Den tyske forbundsrepublikken (Vest-Tyskland) resulterte i stenging av grenser og bygging av Berlinmuren i 1961. Mens DDR rett nok opplevde en viss materiell velstands- økning på 1960-70-tallet, førte tiltagende protester og misnøye på 1980-tallet til Berlinmurens og regimets fall i 1989. 1990 var så året for tysk gjenforening ("die Wende").

Demokratisk var DDR aldri. Formelt fantes det rivaliserende partier (som det liberale og det kristelig-demokratiske), men republikken var i praksis kontrollert av kommunistpartiet ("Sozialistische Einheitspartei Deutschlands", SED) og sikkerhetstjenesten ("Stasi"). Selv om DDR også kunne fremvise positive kvaliteter (lav kriminalitet og arbeidsløshet, samt en del velferdsordninger), hadde staten et åpenbart totalitært preg. Brudd på menneskerettigheter er beskrevet. Internering av annerledes tenkende, det være seg intellektuelle eller punkere, forekom i utstrakt grad. Pressen var underlagt sensur, og kirken hadde en vanskelig stilling (Taylor 2009).

\section{Suicidrater i DDR}

DDR hadde i hele sin førtiårige eksistens høye suicidrater, sammenliknet med $\phi$ vrige europeiske land. Det er likevel verd å merke seg at samlet rate faktisk sank frem til slutten av 1950-tallet. Deretter steg suicidraten markant, fra 24,7/100 000 i 1958 til 30,5 i 1970 (Schulze 1986: 7; Hammerlin \& Enerstvedt 1988: 73). Den britiske historikeren Timothy Ash påpeker at nettopp 1970 var det siste året DDR oppga suicidrater til Verdens helseorganisasjon (WHO), og da med mannlig og kvinnelig rate henholdsvis 35 og 17/100 000 . Tilsvarende tall for Vest-Tyskland var 28 og 15 (Ash 1981: 67).

Rundt 1970 lå DDR på europeisk toppnivå med hensyn til suicidrater, sammen med land som Ungarn, Østerrike, Danmark, Sverige og Finland. Som nevnt var også kvinners rate markant forhøyet i DDR. Videre var suicid i perioder overrepresentert i væpnede styrker og i fengsler (Grashoff 2006). Øst-tysk faglitteratur beskriver at gjennomført suicid var hyppigere i rurale strøk ("Landbevölke rung"), med en overvekt av menn over 50 år (Schulze 1986: 16).

I hvilken grad var DDRs statistikker pålitelige og gyldige? Timothy Ash forteller at en $\varnothing$ st-tysk patolog medga at det fantes direktiver om å reklassifisere suicid, og viser til at raten DDR oppga til WHO i 1970 for uspesifisert voldsom død ("Tote durch alle sonstigen Gewalteinwirkungen") var langt høyere enn Vest-Tysklands (Ash 1981: 67). På den annen side kan det kasuistisk ha forekommet at d $\varnothing$ dsfall etter mishandling i fengsel er blitt kamuflert som suicid (Grashoff 2006: 315). Nettopp Grashoff peker på omfattende rutiner i DDR når det gjaldt likskue og obduksjoner, og at etterundersøkelser tilsier at landets suicidrater hadde en gjennomsnittlig nøyaktighet ("durchschnittlicher Genauigkeit") i internasjonalt henseende (Grashoff 2006: 32). 


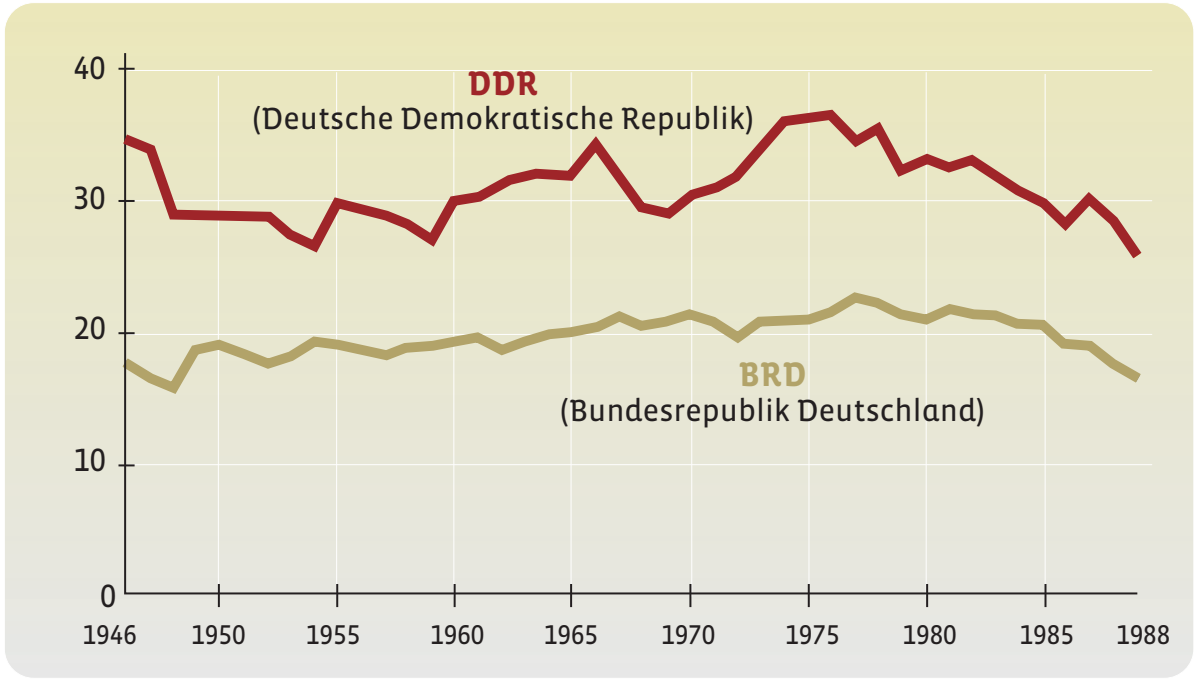

Suicidrater (/100 000) i Vest-Tyskland/Forbundsrepublikken (BRD) og i Øst-Tyskland (DDR) i årene 1946-1989

Et ytterligere argument for en slik vurdering er at statistikken i det gjenforente Tyskland har vist lavere rater for de $\varnothing$ stlige delstatene enn hva som ble oppgitt av DDRs myndigheter, og at dette funnet er konsistent med nedgangen som ble registrert i DDR i 1980- årene, før "die Wende". En parallell utvikling fant sted i Vest-Tyskland (Schmidtke et al 1999; Reiner \& Görtler 1994).

\section{Ideologisk forståelse}

For å belyse myndighetenes håndtering av høye suicidrater i DDR, er det nødvendig å tematisere ideologi. Staten DDR var offisielt basert på marxisme. Hvordan ble suicid forstått innen marxistisk tenkning?

I sin klassiske beskrivelse av arbeiderklassens vilkår i England på 1840-tallet hadde Marx' nærmeste medarbeider Friedrich Engels hevdet at sosial n $\varnothing \mathrm{d}$ kan virke suicidfremmende. Mens suicid ifølge Engels i utgangspunktet hadde vært "et misunnelsesverdig privilegium for overklassen”, førte hunger og arbeidsløshet til at flere arbeidere ("moralske nok til ikke å stjele") suiciderte for å "komme ut av elendigheten" (Engels 1845/1976: 334).

Engels' verk kom til å bli tilgrunnliggende for marxismens syn på suicid: Et fenomen som opprinnelig var ukjent for den jevne mann, men som kunne bre om seg i фkonomiske krisetider. En scene et al 1932).
Arbeidsløshet og mangel på fellesskapsidealer var overveiende den "offisielle" forklaring i DDRs presse når det gjaldt høye suicidrater i enkelte vestlige land (Schulze 1986; Grashoff 2006; personlig meddelelse: Freie Deutsche Jugend-medlemmer, DDR 28. desember 1984). Som drøftet nedenfor, ga denne modellen likefullt et forklaringsproblem: Hvordan kunne man da forstå egne suicidrater, i en stat der arbeidsløshet offisielt ikke eksiterte?

Selv om suicidhandlinger ikke på noe tidspunkt var kriminalisert i DDR, ble fenomenet likevel omtalt som "individuell borgerlig dekadens", eller som et svik mot kollektivet (Grashoff 2006: 273-75). Ikke desto mindre impliserte denne tankegangen en viss forståelse for at mennesker suiciderte dersom de ikke lenger var i stand til å bidra til det sosialistiske fellesskapet. Det kunne vises til at Marx' datter Laura og hennes ektemann Paul Lafargue hadde formidlet at deres suicid i 1911 var relatert til at fysisk svekkelse hindret dem i å ta del i politisk arbeid, og at selveste Lenin hadde bifalt denne handlingen (Krupskaja 1970).

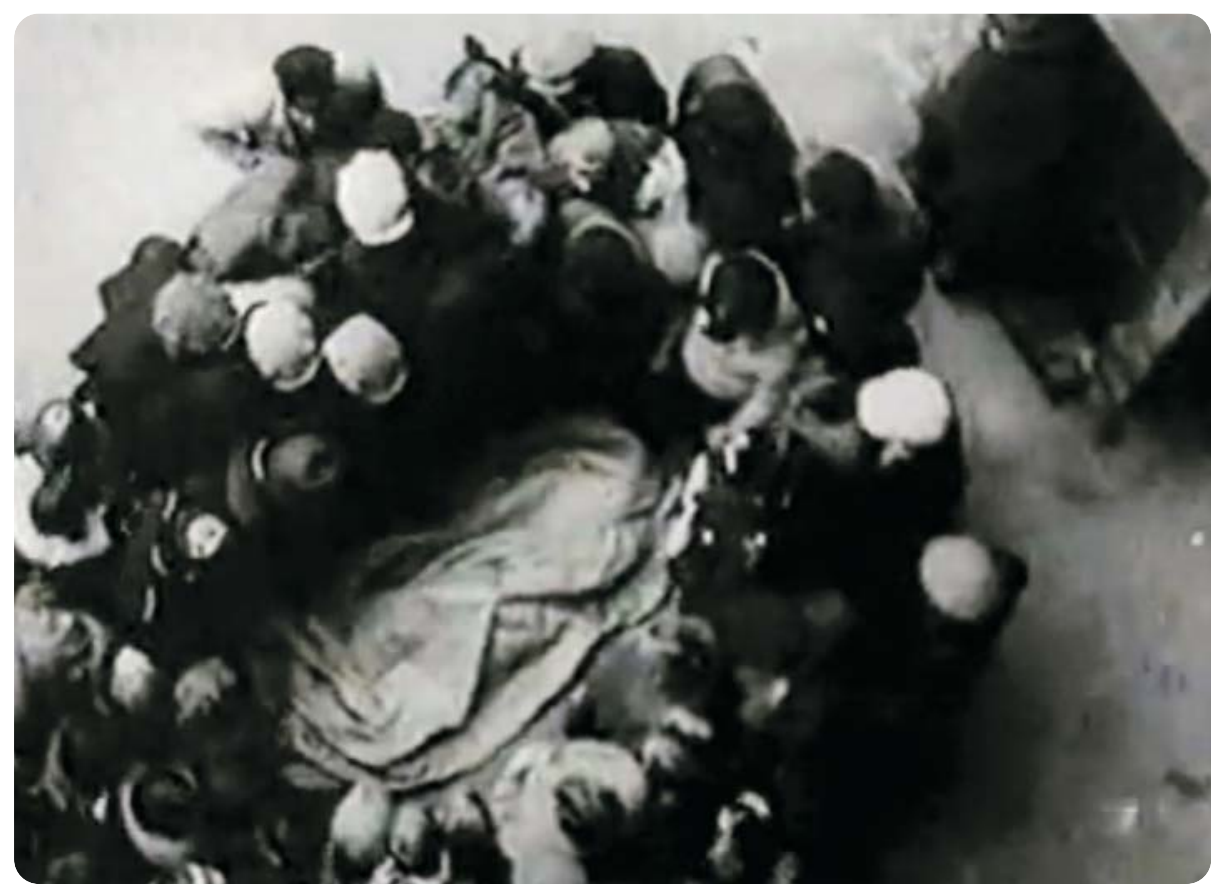

Scene fra filmen Kuhle Wampe oder Wem gehört die Welt? (med-regissert av Berthold Brecht): Forbipasserende samler seg rundt liket av en ung arbeidsløs, som nettopp har kastet seg ut av vinduet (Brecht et al 1932). 


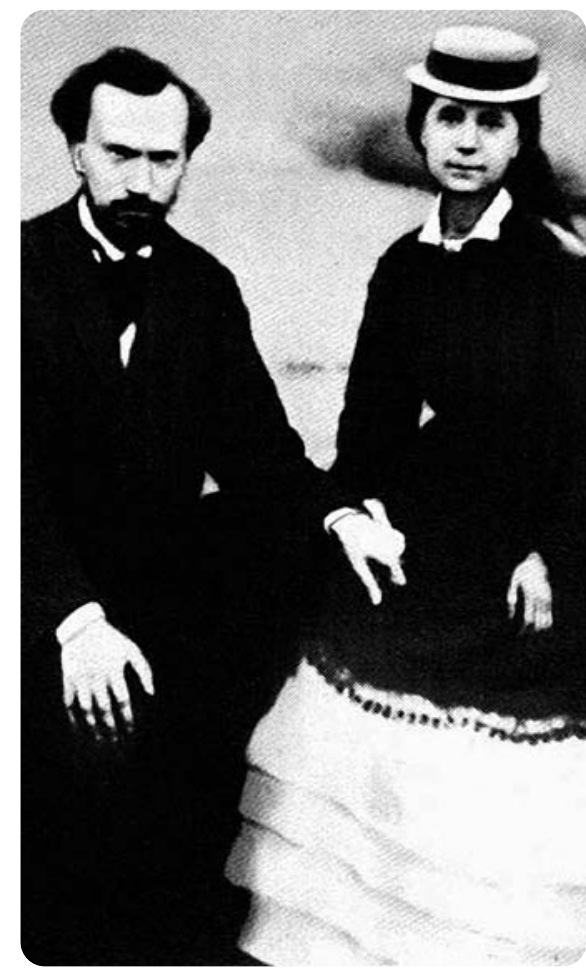

Paul Lafargue og hans ektefelle Laura (datter av Karl Marx), begge død ved suicid den 26. november 1911. I avskjedsbrev skriver Lafargue: "Sunn av legeme og ånd dreper jeg meg selv før den ubønnhørlige alderdom berøver meg livets fornøyelser og gleder en etter en, plyndrer meg for min psykiske og intellektuelle styrke og gjør meg til en byrde for meg selv og andre. (...) Jeg dør i den lykkelige bevissthet om at den sak jeg har viet mine siste 45 år i den nærmeste framtid vil krones med seier. Leve kommunismen. Leve den internasjonale sosialisme". Lenin skal ha sagt til sin hustru: "Hvis du ikke lenger kan arbeide for partiet, må du kunne se sannheten $i$ øynene, og dø som ekteparet Lafargue" (Hammerlin \& Enerstvedt 1988; Krupskaja 1970).

Forsåvidt var ikke dette noen ny ideologi: En tilsvarende etisk forståelse av suicid forefinnes allerede i Platons dialog Lovene (som kan kritiseres for å skissere en stat der individets eksistens utelukkende er legitimert ved nytten det til enhver tid har for kollektivet (Platon 2002, Popper 1943/1971)).
Forklaringsmodeller gitt i DDR på høy suicidrate

Det er nevnt at høye suicidrater i et samfunn uten arbeidsløshet og sosial nød ga et forklaringsproblem for en stat basert på marxistisk tenkning. Flere forklaringsmodeller ble lansert: En lærebok i sosialpsykiatri utgitt i 1971 slår fast at det også i sosialistiske samfunn finnes mennesker som har nedsatt evne til integrasjon i samfunnet. Nettopp sosial isolering kan ha til følge "Dekompensation in der Psychose oder im Suizid". Av den grunn er det en målsetning å arbeide for at isolerte mennesker integreres i fellesskapet ("in die sozialistische Menschengemeinschaft zu integrieren") (Schwartz et al 1971: 88). Også annen litteratur anfører kasuistiske medisinske forklaringer, så som at suicid har skjedd i "et anfall av depresjon". I noen tilfeller ble suicid sett som uttrykk for vestlig påvirkning (Grashoff 2006).

Slike individorienterte forklaringsmodeller besvarte likevel ikke hvorfor suicid forekom hyppigere i en stat basert på en påstått livsbejaende og suicidprofylaktisk ideologi enn i det kapitalistiske Vesten. Flere fagb $\varnothing$ ker utgitt under DDRepoken drøfter derfor muligheten for en etiologi uavhengig av den sosialistiske statsdannelsen. Eksempelvis kunne de høye ratene i området Sachsen ses i lys av en "folkekarakter" ("die sächsische Mentalität") som var beskrevet helt siden reformasjonen: Sakserne var gemyttlige og lekende ("spielerisch"), men samtidig krenkbare, konfliktskye og ikke sjelden med mindreverdighetskomplekser (Schulze 1986: 102). Alternativt kunne ratene forklares med at DDRs befolkning fortsatt var preget av tenkemåter som hadde vært rådende i den tilbakelagte kapitalistiske æra (Grashoff 2006: 282).

Mens nevnte lærebok i sosialpsykiatri fra 1971 fremstår som ukritisk og systemlojal, utkom det i årene før "die Wende" noen forskningspublikasjoner som mer fritt drøfter forklaringer på høye suicidrater (Grashoff 2006: 333). Et eksempel er Andreas Schultzes avhandling ("Dissertation") om suicid og suicidfors $\varnothing \mathrm{k}$ i Leipzig, utgitt i 1986. Forfatteren tematiserer hvordan suicid er et tabu i DDR. Stasi-ansatte har endog ytret at "suicid ikke finnes i sosialismen". Videre nevnes at det kasuistisk er beskrevet hvordan sikkerhetstjenestens forh $\varnothing$ rsmetoder ("fortgesetzte Verhöre beim Staatssicherheitsdienst") kan indusere et "Berlinmursyndrom", med håpløshet og suicidalitet (Schulze 1986: 9). Interessant nok skisseres også at ukritisk tilegnelse av sosialistiske verdinormer gjør ungdommen dårlig rustet for livets realiteter, og at møtet med virkeligheten kan føre til psykiske sammenbrudd. Alkoholisme og høy skilsmisserate vektlegges som etiologiske faktorer, i tillegg til at kvinners utstrakte deltakelse i yrkeslivet i realiteten tilsier dobbeltarbeid og påkjenninger. Innledningsvis beskrives hvordan suicid ikke bare er å anse som en medisinsk variabel, men også som en indikator for samfunnsmessig patologi ("Indikator für den $\mathrm{Zu}$ stand gesellschaftlicher Pathologie") (Schulze 1986: 8).

\section{Forskningens vilkår}

Filmen De andres liv tematiserer at suicidrater ble hemmeligholdt i DDR etter 1977. Dette kan imidlertid nyanseres: Allerede på begynnelsen av 1960-tallet var ratene blitt unndratt offentlighet, ved at de bare var tilgjengelige for forskere, begrunnet med at offentliggjørelse kunne indisere nye suicid (Ash 1981: 67, Grashoff 2006). Forsåvidt ble det i perioden argumentert på liknende måte i Vesten når det gjaldt åpenhet om fenomenet suicid. Derimot var begrunnelsen for hemmeligholdelsen etter 1977 ganske unik: Departementet ("Gesundheitsministerium") hevdet, sannsynlig med direktiv fra sentralkomiteen i SED, at ratene kunne utnyttes av "klassefiender" (Schulze 1986: 8, Grashoff 2006: 329). Muligheten for kvantitativ forskning og sammenlikning ble på denne måten sterkt begrenset, selv om det også etter 1978 skal ha vært eksempler på at fagpersoner fikk ikke-reglementert tilgang til statistikker. Etter gjenforeningen i 1990 er så de hemmeligholdte ratene blitt publisert (Reiner \& Görtler 1994). 
Kvalitativ forskning og dybdeanalyse var i minst like stor grad underlagt kontroll. Særlig på 1960- og 70-tallet forekom sensur av forskningspublikasjoner, og det var en ledende føring at høye suicidrater ikke skulle ses som relatert til sosiale forhold eller "sosialismen" (Grashoff 2006: 304, 326). Psykodynamisk tradisjon, med sin vektlegging av enkeltindividets aggresjon som etiologisk for suicid og psykopatologi, ble i stor grad ansett som "borgerlig", og uforenlig med sosialismens grunnprinsipper (Grashoff 2006: 322, Freud 1933/1991)

I likhet med marxistisk litteratur i Vesten var fagb $\varnothing$ ker fra DDR preget av hyppig bruk av termen "dialektikk", som generell betegnelse på relasjoner og mulige motsetninger (eksempelvis mellom biologisk disposisjon og psykososiale faktorer (Schulze 1986)). Videre ble vestlige tradisjoner, så som eksistensialismen, ofte omtalt som "borgerlig" eller "irrasjonell" (Schwarz et al 1971: 21). Retrospekt synes det likevel som medisinsk faglitteratur fra DDR mottok impulser fra utland, og også kunne formidle nytenkning. Sozialpsychiatrie in der sozialistischen Gesellschaft inneholder kapitler om så vel musikksom arbeidsterapi, samt pasienters mulighet for medvirkning i institusjoner ("Patientenrat"), og har hyppige referanser til vestlig (endog norsk) faglitteratur. Tilsvarende viser Andreas Schulzes avhandling fra 1986 til den amerikanske legen Thomas Szasz' "antipsykiatriske" forfatterskap, samt psykodynamiske forklaringsmodeller (som refereres med en relevant innsigelse angående generaliserbarhet) (Schwarz et al 1971; Schulze 1986).

Hemmeligholdelse og sensur viser likevel at suicidologisk forskning ikke hadde frie vilkår i DDR. Dette gjelder også selvmordsforebyggende arbeid, som først ble tillatt på 1980-tallet, etter at kirken hadde tatt initiativ (Grashoff 2006). Myndighetenes kontroll av informasjon var særlig utpreget hvis suicid og selvdestruksjon kunne tolkes som systemkritikk, og dermed sette regimet i et dårlig lys. Et eksempel skal nevnes: Pastor Oskar Brüsewitz.

\section{Pastor Oskar Brüsewitz' død}

Oskar Brüsewitz (1929-76) var ansatt i menigheten i distriktet Rippicha nær byen Zeitz, etter at han i voksen alder hadde omskolert seg fra skomaker til evangelisk prest. Han fremsto som utradisjonell og ukonvensjonell, også i sin kritikk av DDR-regimet. Siden 1961 var han registrert hos sikkerhetstjenesten. Den 18. august 1976 forfattet han et brev til egen menighet, der han delvis ga uttrykk for selvanklager, men også at han om få timer ville møte sin frelser. Dernest stilte han seg opp foran Michaeliskirche i Zeitz, overhelte seg med bensin og tente på. På forhånd hadde han montert plakater med slagord mot kommunistisk undertrykkelse (Brüsewitz-Fecht 2009).

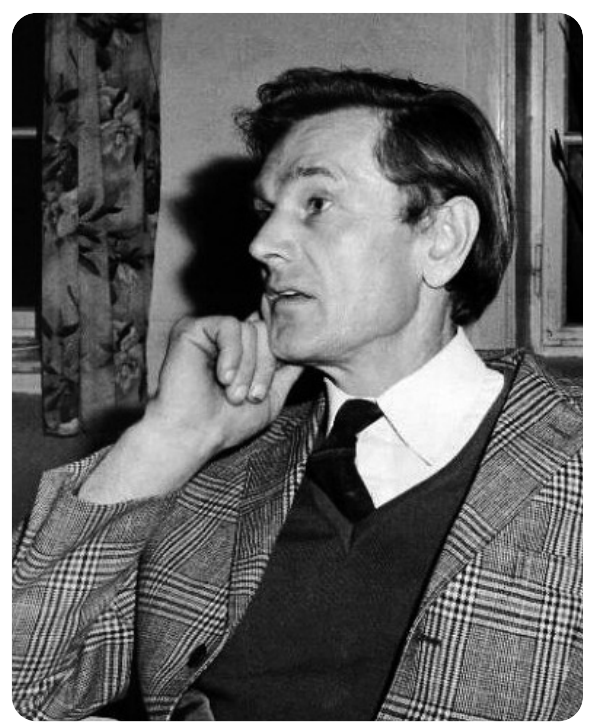

Oskar Brüsewitz

Var Brüsewitz' død å forstå som suicid hos en emosjonell ustabil person? Eller foretok han en politisk offerhandling? (Noe som etter Durkheimtradisjonen ikke kan defineres som suicid (Baechler 1980: 72)). Avisen Neues Deutschland og andre partiorganer fors $\varnothing$ kte ensidig å sannsynliggjøre det førstnevnte, ved ironisk å kommentere Brüsewitz' forhistorie, og å hevde at hans ukonvensjonelle stil var uttrykk for alvorlig psykisk lidelse. Uttalelser fra kolleger innen kirken ble tatt til inntekt for et slikt syn (BrüsewitzFecht 2009: 95-97). Reaksjonene i Vesten var annerledes. Noen dager senere skrev Aftenposten på lederplass: "Som kjent helte han bensin over seg og tente på i protest mot de $\varnothing$ st-tyske myndigheters politikk overfor de troende i DDR, og han døde av sine skader i forgårs". (Aftenposten 25. august 1976).

I årene etter 1969, da Jan Palach brente seg til døde på torget i Praha som protest mot den sovjetiske innmarsjen, hadde tilvarende handlinger funnet sted så vel i $\varnothing$ stblokken som i vestlige land (Andriolo 2006; Grashoff 2006). Heller ikke Norden gikk fri: "Jag skall bränna meg til döds. Och jag gör det i protest mot det här jävla systemet”, skal en arbeids- og bostedsløs ung mann ha sagt før han satte fyr på seg selv i Gøteborg i 1981 (Hammerlin \& Enerstvedt 1988 : 70-71). Forskjellen er likevel åpenbar: I Vesten kunne hendelsene diskuteres i en uavhengig presse, og heller ikke forskningen var underlagt sikkerhetstjenestens direktiver.

\section{DDRs suicidrater - sett i retrospekt}

Suicid er et multifaktorielt fenomen, og endringer i suicidrater har sjelden noen åpenbar eller entydig årsak. Tyve år etter at staten DDR opphørte, kan man likevel peke på følgende for å belyse de høye ratene:

Geografisk omfattet DDR områder som hadde ligget høyt i all den tid suicidrater var registrert (for Sachsens del helt tilbake til 1784 (Schultze 1986: 12)).

Såvel Sachsen som Preussen blir nevnt i faglitteratur fra mellomkrigstiden som eksempler på regioner med høye suicidrater i den protestantiske delen av befolkningen (Halbwachs 1930/1978). Fransk Durkheimtradisjon har nettopp pekt på at en regions suicidrater i alminnelighet endres svært langsomt, og har også tendert mot å se en sammenheng mellom høye rater og protestantisme (Baechler 1980). Den marxistisk (og ateistisk) funderte staten DDR “arvet" på denne måten en problematikk som historisk kan føres tilbake til epoken før Tysklands rikspolitiske samling i 1871. Selv om terminologien virker fremmed, kan derfor DDRforskernes vektlegging av "sachsisk folkekarakter" og prekommunistisk tenkemåte ha relevans. 
Videre var de $\varnothing$ stlige områdene av Tyskland utsatt for stadige bombetokter og krigshandlinger i den annen verdenskrigs sluttfase. Moderne historikere har pekt på at de sovjetiske troppene begikk omfattende overgrep mot sivilbefolkningen, noe som åpenbart har fort til etterreaksjoner og mulig suicidalitet.

Selv om DDRs målsetning om kvinners deltakelse i arbeidslivet kan ses på som ideell, innebar den i stor grad dobbeltarbeid og påkjenninger for kvinner (Grashoff 2006: 40)

Imidlertid er det verd å merke seg at både menn og kvinners suicidrater periodevis sank i DDR frem til slutten av 1950-tallet. Det er fristende å se dette i sammenheng med at politiske begivenheter etter Stalins død i mars 1953 indikerte at det på den tiden fantes håp om sosial endring i flere $\varnothing$ stblokkland. Først etter at oppstandene i DDR (juli 1953), Polen (juni 1956) og Ungarn (oktobernovember 1956) var slått ned, viste suicidratene en markant stigning, som kom til å vedvare utover 1960-tallet. Byggingen av Berlinermuren i 1961 var en konkret manifestasjon av at den etterlengtede endringen ikke ville komme, i stedet var fluktveien til Vesten blokkert.
Samtidige tvangstiltak (som kollektivisering av landbruket i 1960) kan ha forsterket en felles opplevelse av håpløshet (Grashoff 2006: 210). Moderne suicidologisk forskning har vist at nettopp håpløshet er en viktig prediktor for suicidrisiko (Herrestad 2009).

I et egopsykologisk perpektiv kan suicid i DDR ses i lys av at det var risikabelt og knapt tillatt å verbalisere aggresjon mot autoriteter, og at aggresjon derfor lett "ble vendt innover". Tilsvarende kan man i et selvpsykologisk perspektiv vise til at mennesker som ikke passet inn i det foreskrevne "sosialistiske folkefellesskapet", overveiende var henvist til en ensom og identitetsl $\varnothing$ s tilværelse, iallfall før protestbevegelsen grep om seg på 1980-tallet (da også suicidratene sank) (Thorvik 2008).

\section{Eksempler fra Skandinavia}

På denne måten kan det postuleres et mangfold av forklaringsmodeller på suicidratene i DDR. Den beskrevne praksisen med sensur og hemmeligholdelse vitner uansett om at myndighetene så for seg at de høye ratene ville bli sett som en indikator på et dysfunksjonelt politisk system. Dette skjedde da også.

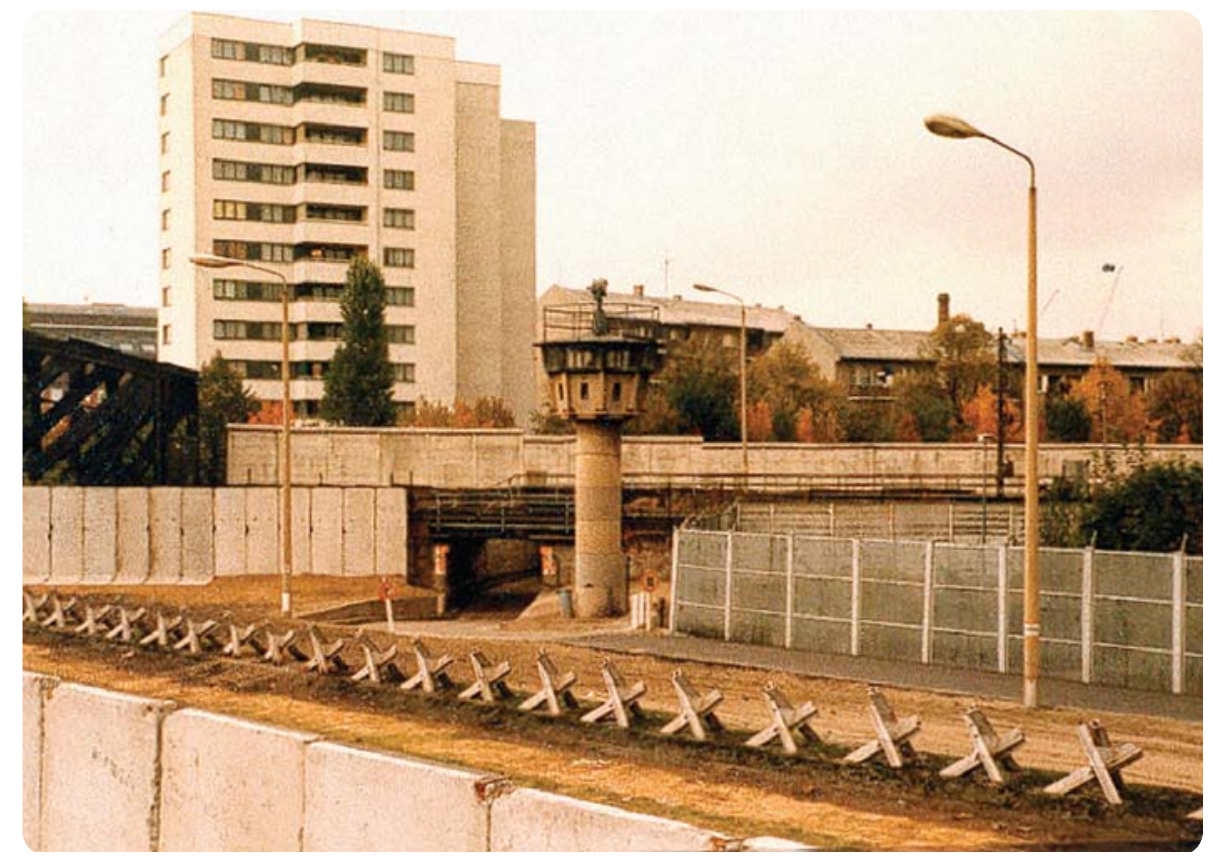

Utsnitt av Berlinmuren (Liesenstrasse), ca 1980. Foruten selve muren ses overflatehinder, piggtrådgjerder, lyskastere og vakttårn.
Eksempelvis hevdet den kjente øst-tyske opposisjonelle Robert Havemann (1910-82) i intervju med den franske avisen Le Monde i 1978 at den markerte forskjellen mellom suicidrater i DDR og Vest-Tyskland var relatert til DDRs "økonomiske og politiske basis"

(Hammer 1978: 44).

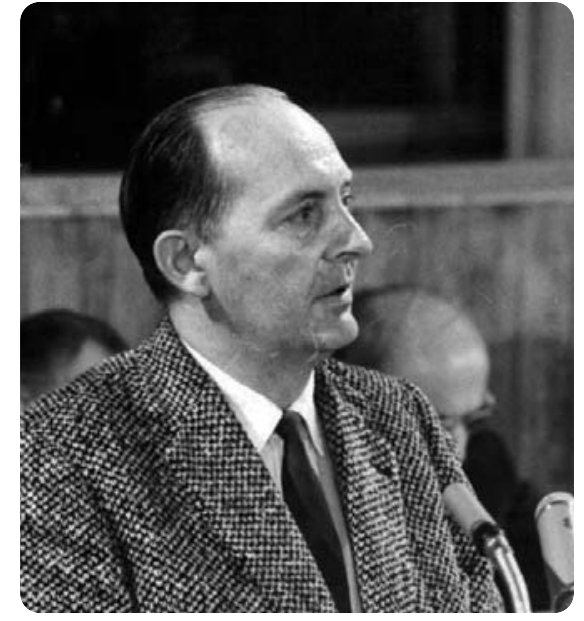

Robert Havemann

Man kan innvende at DDR er et ekstremt eksempel. En totalitær ideologi lå til grunn for statsdannelsen, og målsetningen om å eliminere suicid var basert på en tilsvarende ideologisk, men ufullstendig forståelse av fenomenet.

På den annen side er det tradisjon innen den filosofiske retningen kalt fenomenologi nettopp å ta utgangspunkt i det ekstreme. Fenomener som tenderer mot å forsvinne i "normalitetens flyt" vil da tre klarere frem. Og det finnes vel å merke eksempler fra andre deler av verden på at suicidrater blir sett som en politisk indikator, endog fra vårt hjemlige (og demokratiske) Skandinavia. I juli 1960 uttalte den amerikanske president Eisenhower at "en vennligsinnet europeisk nasjon" på grunn av "overdreven sosialisme hadde opplevd en forferdende drukkenskap ledsaget av meget høy selvmordsprosent". Uttalelsen var sannsynlig myntet på Sverige eller Danmark, og vakte store reaksjoner der (Aftenposten 28.- 29. juli 1960). Selv om analysen nok var overfladisk, ligger den beskrevne tenkemåten til grunn: Høye suicidrater er ikke bare et medisinsk anliggende, men indikerer et dysfunksjonelt politisk system. 
Et mer dyptgående fors $\varnothing \mathrm{k}$ på analyse kom fra den engelske filmregiss $\varnothing$ ren Peter Watkins (kjent i Norge for Edvard Munch). Filmen "70-årenes folk" ble laget i Danmark i 1976, altså på et tidspunkt da danske suicidrater var blant de høyeste i Europa. I Danmarks Radios presseom tale av filmen heter det: "Det, han (Watkins) har funnet i halvfjerdsenes danske folk, er en højt udviklet evne til at feje problemerne ind under gulvtæppet. I Danmark gælder det om først og fremmest at have det hyggelig, man $t \varnothing r$ ikke se virkeligheten i фjnene. Man vil ikke åbne seg for hinanden, vise følelser. Facaden skal bevares for enhver pris, også den pris, at det går ut over mennesker i nød og især de unge, der tegner seg for en meget stor del af de selvmord og selvmordsfors $\varnothing \mathrm{g}$, der finder sted her i landet" (Aftenposten 10. april 1976).

Også her postuleres en sammenheng mellom suicidrater og politikk, om enn mer indirekte. Målsetningen om å skape en velferdsstat har medført en uengasjert og fasadepreget væremåte hos "folk flest", noe som igjen har resultert i høye suicidrater.

\section{Indikator på samfunnets patologi?}

Beskrevet praksis i DDR viser at suicidrater ikke bare har en medisinsk, men også kan bli tillagt en politisk betydning. For så vidt er dette ikke enestående.

Eksempelvis er "spedbarnsdødelighet" å anse som en utvidet parameter, som gir en generell indikasjon på et samfunns hygiene, ernæring og fungerende helsetilbud.

Erfaringene fra DDR viser også noe annet: På samme måte som ytrings- og trykkefrihet, er en uavhengig forskning og statistikkføring grunnleggende for det vi kaller et demokrati.

En annen spørsmålsstilling er hvorvidt det er berettiget å tillegge suicidrater en politisk betydning, som en indikator på et samfunns funksjon eller dysfunksjon. Denne problemstillingen er i seg selv verdt en artikkel, og fordrer ikke minst en nærmere definisjon av "politikk". Avslutningsvis skisseres noen korte betraktninger omkring dette:
Det er nevnt at suicidrater innen en region i allminnelighet endres langsomt. Et demokratisk og humanistisk regime kan på denne måten "arve" høye suicidrater. Medisinsk sett har suicid vært knyttet til psykose og depresjon, og det er ikke uten videre gitt at disse har konstant prevalens i ulike land og kulturer. Enn videre vil suicidrater kunne påvirkes av utenforliggende faktorer, det være seg krig eller andre hendelser som samler befolkningen (også i nøytrale land).

Religion og grad av industrialisering vil ha betydning. Det samme vil endringer med hensyn til hvordan suicid registreres.

Suicid er et multifaktorielt fenomen, og noen sammenheng mellom rater og politikk er derfor ikke umiddelbar. På den annen side viser DDR-eksemplet at det er mulig å se stigningen på 1960 tallet i lys av at politiske veivalg impliserte en kollektiv håpløshet. Dersom det påligger statsstyrelsen å gi innbyggerne håp og fremtidsutsikter (som det faktisk gis føringer om i den amerikanske uavhengighetserklæringen), kan - med alle de forbehold som er tatt - en stigende suicidrate over tid ses som uttrykk for en feilslått politikk, eller (som forskerne i DDR var modige nok til å medgi): Indikator på samfunnets patologi.

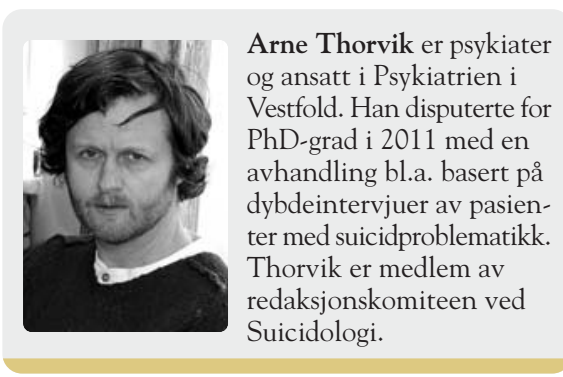

\section{Referanser}

Andriolo K (2006). The twice-killed: Imagining protest suicide. American Anthropologist; 108 (1) : 100-113.

Ash TG (1981). Und willst du nicht mein Bruder sein ... Die DDR heute. Reinbek bei Hamburg: Rowohlt Verlag (oversatt fra engelsk originalutgave).

Baechler J (1980). A strategic theory. Suicide and Life-Threatening Behavior. Vol 10 (2): 70-99.

Brecht B, Dudow S, Ottwalt E (1932). Kuhle Wampe oder Wem gehört die Welt? Berlin: Prometheus Film.
Brüsewitz-Fecht R (2009). Das Kreuz und die Flamme - der Fall Oskar Brüsewitz. Halle: Projekte-Verlag Cornelius.

Donnersmarck FH von (2006). Das Leben der Anderen. München: Wiedemann \& Berg Filmproduktion.

Engels F (1976). Die Lage der arbeitenden Klasse in England. I: Marx-Engels Werke, bind 2: 225-506 (http://www.mlwerke.de/me/me02/me 02_324.htm) (første gang utgitt i 1845).

Freud S (1991). New introductory lectures on psychoanalysis (lecture 35). London: Penguin Books (første gang utgitt i 1933).

Grashoff U (2006). "In einem Anfall von Depression” - Selbsttötungen in der DDR. Berlin: Ch. Links Verlag.

Halbwachs M (1978). The causes of suicide. London: Routledge (første gang utgitt i 1930).

Hammer JP (1978). Robert Havemann. Le Monde: 21. januar 1978/New German Critique, Autumn 1978: 37-46.

Hammerlin Y \& Enerstvedt RT (1988). Selvmord i virksomhetsforståelsens perspektiv. Oslo: Falken Forlag.

Hammerlin Y (2010). Samfunnet og hverdagslivets lidelsesproduksjon og selvmordsproblematikken. Ansatser til kritisk refleksjon. Suicidologi 15 (2): 30-36.

Herrestad H (2009). Om begrepet håp. Suicidologi; 14 (1): 16-20.

Krupskaja N (1970). Reminiscences of Lenin. International Publishers. (http://www.marxists.org/ archive/krupskaya/works/rol/index.htm).

Platon (2002). Lovene. Oslo: Vidarforlaget.

Popper KR (1971). The open society and its enemies. New Jersey: Princeton University Press (første gang utgitt i 1943).

Reiner HD \& Görtler E (1994). Die Suizidsterblichkeit der Geburtsjahrgänge in beiden Teilen Deutschlands. Soz Präventivmed; 39: 198-208.

Schmidtke A, Weinacker B, Stack S \& Lester D (1999). The impact of the reunification of Germany on the suicide rate. Archives of Suicide Research; 5: 233-39.

Schulze A (1986). Selbstmord und Selbstmordversuche in Leipzig - Zur Erklärung suizidaler Handlungen in der DDR. Regensburg: S. Roderer Verlag.

Schwarz B, Weise K \& Thom A (1971). Sozialpsychiatrie in der sozialistischen Gesellschaft. Volkseigener Betrieb Georg Thieme, Leipzig.

Taylor F (2009). Berlinmuren. Oslo: Cappelen Damm.

Thorvik A (2008). Å stå på Freuds skuldre: hovedlinjer i psykodynamisk forståelse av suicid. Suiciologi; 13 (3): 5-9.

Vetlesen AJ (2009). Frihetens forvandling. Oslo: Universitetsforlaget. 